\title{
Synaptic plasticity in infralimbic cortex mediates socially-acquired nicotine self-administration
}

\author{
Hao Chen ${ }^{*}$, Tengfei Wang, Wenyan Han \\ From 14th Annual UT-KBRIN Bioinformatics Summit 2015 \\ Buchanan, TN, USA. 20-22 March 2015
}

\section{Background}

Social environment plays a critical role in the initiation of cigarette smoking among adolescents. It has been established that nicotine, the principal psychoactive ingredient of tobacco products, has both aversive and rewarding properties. Using olfactogustatory stimuli as the sensory cue for intravenous nicotine self-administration, we have shown that social learning of nicotine contingent odor cue prevented rats from developing conditioned taste aversion (CTA) and allowed them to instead establish stable nicotine self-administration. We also have shown that infralimbic cortex is a critical brain region for the effect of social learning in reversing nicotine conditioned aversion. We hypothesized that gene expression changes related to synaptic plasticity in infralimbic cortex underlies this effect of social learning.

\section{Materials and methods}

We trained rats to self-administer intravenous nicotine in either an inducing or a neutral social environment, with contingent olfactogustatory cues for three days. Rats were then tested using a standard CTA protocol on day four. Rats were killed immediately after the CTA test and infralimbic cortex was dissected. RNA was then extracted for transcriptome sequencing using the Ion Proton instrument. Reads were mapped to the reference genome (rn6). Gene expression levels were estimated using HTSeq. The RefSeq database was used as the reference. DESeq2 was then used to normalize the expression levels and to identify statistically significant differences between the groups placed in the inducing and neutral social environments.

\footnotetext{
* Correspondence: hchen@uthsc.edu

Department of Pharmacology, University of Tennessee Health Science Center, Memphis, TN38163, USA
}

(c) 2015 Chen et al. This is an Open Access article distributed under the terms of the Creative Commons Attribution License (http:// creativecommons.org/licenses/by/4.0), which permits unrestricted use, distribution, and reproduction in any medium, provided the original work is properly cited. The Creative Commons Public Domain Dedication waiver (http://creativecommons.org/publicdomain/ zero/1.0/) applies to the data made available in this article, unless otherwise stated.

\section{Results}

Gene set enrichment analysis (GSEA) supported our hypothesis that genes related to synaptic plasticity are preferentially regulated by the social environment.

\section{Acknowledgements}

Funding for this research was provided by the UTHSC Center for Integrative and Translational Genomics.

Published: 23 October 2015

doi:10.1186/1471-2105-16-S15-P1

Cite this article as: Chen et al:: Synaptic plasticity in infralimbic cortex mediates socially-acquired nicotine self-administration. BMC Bioinformatics 2015 16(Suppl 15):P1.
Submit your next manuscript to BioMed Central and take full advantage of:

- Convenient online submission

- Thorough peer review

- No space constraints or color figure charges

- Immediate publication on acceptance

- Research which is freely available for redistribution Submit your manuscript at
www.biomedcentral.com/submit C BioMed Central
- Inclusion in PubMed, CAS, Scopus and Google Scholar 